\title{
$\mathrm{APR}$ 에서 사용하는 SDS 특성 분석에 관한 연구
}

\section{A Study on the Analysis of Characteristics for Safety Depressurization System of Advanced Power Reactor}

\author{
이해철* \\ Lee, HaeChul
}

\begin{abstract}
The purpose of this study analysis is evaluation of Safety Depressurization System function on PWR plant. The Safety Depressurization System is a system which releases steam from the pressurizer of Reactor Coolant System(RCS) and depressurizes RCS. There is a similar system in Boiling Water Reactor(BWR) type plant but the SDS with In-Containment Refueling Water Storage System(IRWST) is a new system to Pressurized Water Reactor(PWR). The current worldwide trend in a new PWR design is to implement a SDS with IRWST because of the advantages in installing IRWST. There have been also trials to install a SDS with IRWST to newly ordered domestic plant was that the domestic technical level for analysis and design of the system was not sufficient to do work.
\end{abstract}

Key words : Pressurized Power Reactor(PWR), Safety Depressurization System(SDS), Advanced Power Reactor(APR), In-Containment Refueling Water Storage Tank(IRWST), Boiling Power Reactor(BWR)

\section{요 지}

안전감압시스템(SDS)의 주요 기능은 시스템의 압력이 운전 제한치를 초과하는 비정상적인 상황이 일어날 경우에 빠른 시간 내에 안정적으로 발전소의 압력을 감압시켜 발전소를 정상화하는데 그 목적이 있기 때문에 이러한 기능을 만족시키기 위한 안 전감압시스템의 설계 인자가 무엇인가를 찾고자 하였다. 시스템의 압력을 조절하는 가압기 상단부분의 안전 감압밸브를 열어 증 기를 배출함으로 시스템의 압력을 낮추는데 증기 배출을 위한 배관 설계에 있어서 배관내의 과도 유동 상태를 실제 발전소 여 건에 맞도록 전산 프로그램을 개발하여 안전감압시스템의 배관에서의 증기의 과도 유동 해석을 수행하였고 그 결과를 토대로 안전감압시스템의 배관 및 배관 지지대 설계에 활용하고자 하였다.

핵심용어 : 가압경수로형 원자력발전소, 안전감압시스템, 신형 원자력발전소, 재장전수 저장탱크, 비등경수로형 원자력발전소

\section{1. 서}

지금 고유가 시대와 더불어 환경관리에 모든 선진국들이 심혈을 기울이고 있으며 에너지원 확보가 무엇보다도 큰 과 제로 안고 있다. 그러나 현재까지 개발된 새로운 에너지원들 은 이렇다 할 수 있는 성과를 거두지 못하고 있다. 이에 현 재 가용한 에너지원으로 가장 합당한 에너지원인 원자력 에 너지를 활용한 원자력 발전소의 건설이 유일한 방법이라는 결론을 최근 세계의 선진국들이 내고 있다. 국내에서도 이와 같은 세계적인 추이를 인지하고 정부의 방침을 설정하였고, 현재 우리나라의 전력에 있어서 $40 \%$ 이상이 원자력 발전소에 서 공급하고 있으며, 조만간 $50 \%$ 에 도달할 것으로 예상된다. 일본 후쿠시마 원전 사고의 경우에서 알 수 있듯이 원자력 발전소는 무엇보다도 방사선 누출 사고와 같은 사고로부터의
안전성 확보가 중요하다. 사고 상황중에서 발전소 시스템의 압력이 증가될 경우에 이를 감압시키기 위해 설계된 시스템이 안전감압시스템이다. 본 연구는 원자력 발전소의 핵증기공급 시스템에서 안전감압 시스템에 대한 내용이다. 안전감압시스 템은 발전소가 운전중 예기치 못한 비정상적인 이유로 시스템 의 압력이 운전제한치의 $110 \%$ 이상을 초과할 경우에 발전소 를 빠르게 안정시키기 위한 시스템이다. 본 연구의 대상이 되는 발전소는 신형 원자력발전소(APR)로서 감압을 위해 방 출되는 계통의 증기를 격납고에 설치되는 재장전수 저장탱크 로 직접 분출하게 된다(H.H. Safwat, 1976). 증기분사기 설 계에 있어서 고려해야 될 수력적 하중은 신고리 3,4 호기 신 설개 개념에 의해 설계된 격납고 저장충수조(In-containment Refueling Water Storage Tank: IRWST) 설계 관련자료 (Lubin, 1992)에 의하면 IRWST에 가장 중요하게 작용하는 
하중은 안전/방출밸브의 순간 개방에 의한 물/공기 방출하중 이라고 지적하고 있듯이 초기 물/공기 방출하중과 chugging 현상에 의한 압력변동 하중으로 나눌 수 있다. 과도 유동을 해석하기 위해 개발한 코드는 방출밸브의 개방시 발생되는 물/공기 방출하중 평가를 위해서 필요한 경계조건인 증기분사 기에서의 유속 및 압력변화를 계산하기 위해 해석적으로 접 근하여 분석할 수 있어야 한다. 따라서 이러한 고압 및 고온 의 증기가 안전감압시스템을 통과할 때에 배관 및 배관에 미 치는 열 - 수력적 특성을 파악하고 또한 고에너지의 증기가 재장전수 저장탱크에 분출될 때 재장전수 저장탱크에 미치는 열 수력적인 특성을 분석하고자 한다.

\section{2. 코드 개발}

개발된 코드는 원자력발전소 설계에 적용된 안전감압시스 템의 배관계에 있어서의 동적이며 동시에 수력적 특성을 분 석 및 평가하기 위한 FORTRAN 프로그램으로서 가압기의 방출밸브 후단부터 IRWST 수조에 잠겨 있는 증기분사기 전 단까지를 모델화하여 계산하도록 하였다. 안전감압시스템의 배관계는 발전소 정상 운전시에는 purge 등을 위하여 비응축 성 비활성기체로 채워져 있으며 하류의 증기분사기 전단 부 분은 수조속에 잠기어 있다. 이와 같은 초기 조건뿐만 아니 라, 방출밸브 개방시에는 고온 및 고압의 물/수증기가 방출되 면서 이것과 초기 비응축성 기체와의 움직이는 경계면이 형 성되고, 또한 하류쪽으로 전달된 압력으로 인하여 초기 잠긴 부분의 물기둥의 이동도 모사되어야 한다. 그리고 비응축성 기체/물기둥의 경계의 소거(water clearing)와 수증기/비응축성 기체의 경계의 소거(air clearing)를 모사할 수 있어야 하며, Nakamura(1977), Hammitt(1980), Anderson(1984) 등 많은 연구에서 나타내어진다.

원자력 발전소의 안전감압시스템의 특성 분석을 위한 전용 프로그램의 계산에 대한 흐름을 나타내었다.

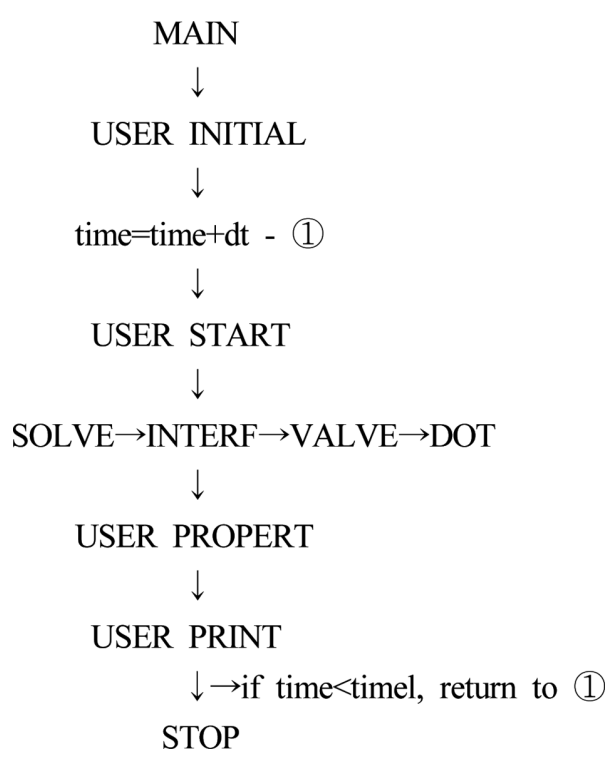

개발 프로그램의 주요 subroutine의 계산내용은 다음과 같 다. 즉,
MAIN : 계산시작과 입출력제어, 그리고 계산 정지

SOLVE : 특성선법에 의한 방정식 계산

VALVE : 가압기 방출밸브 개방 모사

MDOT : 가압기 방출밸브를 통한 방출 유량계산

INTERF : 방출유체중 개스물과 수증기깨스의 경계면의 거동 계산

USER : 사용자 입력 내용 및 계산 초기화, 주된 계 산과 출력 제어

$\cdot$ INITIAL : 계산 초기조건 설정

-START : 매 계산시 주요 계산 제어

·PROPERT : 매 계산시 배관전체의 node에 대한 계산값 및 물성치 계산

·PRINT : 출력제어 등 이다.

1 차 계통인 원자로냉각재계통에 과도현상이 발생할 때, 안 전감압계통에서의 압력 변화는 배관계의 기계적 건전성뿐만 아니라, 방출된 유체가 수조 내에서 기포를 형성하면서, 수조 에 미치는 주기적 하중의 영향이 매우 크기 때문에 배관 내 에서 우체의 거동 분석은 전체 증기 방출 계통의 특성을 파 악하는데 중요한 요소가 된다. 또한 $17.23 \mathrm{MPa}$ 의 포화압력 고압 상태의 가압기로부터 대기압 상태의 수조로 형성되는 기체 및 유체의 배관 유동은 어느 시점부터 이상 유동의 쵸 킹(choking)을 유발하게 됨으로서 계통의 성능분석에 있어서 도 배관 내의 유동현상분석은 필수적이다.

본 해석방법의 지배방정식은 다음과 같다.

질량보존방정식: $\frac{\partial \rho}{\partial t}+v \frac{\partial \rho}{\partial x}+\rho \frac{\partial v}{\partial x}=0$

운동량보존방정식: $\frac{\partial v}{\partial t}+v \frac{\partial v}{\partial x}+\frac{1}{\rho} \frac{\partial p}{\partial x}=-\frac{f}{D} \frac{v|v|}{2}$

에너지보존방정식:

$\frac{\partial h}{\partial t}+v \frac{\partial h}{\partial x}-\frac{1}{\rho}\left(\frac{\partial h}{\partial t}+v \frac{\partial p}{\partial x}\right)=\frac{f}{D} \frac{v^{2}|v|}{2}-\frac{4 h_{c}\left(T-T_{\text {wall }}\right)}{\rho D}$

계산 알고리즘은 특성방정식 및 초기/경계조건 등을 일정한 시간간격격자를 사용하여 물, 공기, 그리고 증기에 대해서 시 간에 대한 explicit기법을 사용한 유한차분법을 적용하여 정리 하면 다음과 같은 차분식으로 표시된다.

$$
\left(p_{P}-p_{R}\right)+\rho_{R} a_{R}\left(v_{P}-v_{R}\right)=
$$

$\frac{f_{R}}{D} \frac{\rho_{R}}{2} v_{R}\left|v_{R}\right|\left\{(k-1) v_{R}-a_{R}\right\} \Delta t-\frac{4 h_{c}\left(\frac{p_{R}}{\rho_{R} \bar{R}}-T_{\text {wall }}\right)}{D}(k-1) \Delta t$

$\left(p_{P}-p_{S}\right)+\rho_{S} a_{S}\left(v_{P}-v_{S}\right)=$

$\frac{f_{S}}{D} \frac{\rho_{S}}{2} v_{S} \mid v_{S}\left\{\left\{(k-1) v_{S}-a_{S}\right\} \Delta t-\frac{4 h_{c}\left(\frac{p_{S}}{\rho_{S} \bar{R}}-T_{\text {wall }}\right)}{D}(k-1) \Delta t\right.$

$\left(\rho_{P}-\rho_{Q}\right)-\frac{1}{a_{Q}^{2}}\left(p_{P}-p_{Q}\right)=$

$-\frac{1}{2} \frac{f}{D}(k-1) \frac{\rho_{Q}}{a_{Q}^{2}} v_{Q}^{2}\left|v_{Q}\right| \Delta t-\frac{4 h_{c}}{a_{Q}^{2} D}\left(\frac{p_{Q}}{\rho_{Q} \bar{R}}-T_{\text {wall }}\right)(k-1) \Delta t$ 
여기서 아래첨자 $R, S$, 그리고 $Q$ 는 특선곡선이 격자점 사이 에 존재할 경우는 두 격자점값에서 선형보간법에 의해 값을 구해 계산을 수행한다. 상태방정식은 stream table(Crane, 1982)을 사용하였다.

프로그램의 주요 입력변수 내용(subroutine USER)은 다음 과 같다. 즉,

$\begin{array}{ll}\text { TIME } & \text { : 계산 시간 }(\mathrm{sec} .) \\ \mathrm{DT} & \text { : time increase for a time step (sec.) } \\ \mathrm{DX} & \text { : axial distance for a node or cell }(\mathrm{m}) \\ \mathrm{NL} & \text { : node number for total tube length } \\ \mathrm{TIMEL} & \text { : 계산 종료 시각 }(\mathrm{sec} .) \\ \mathrm{PO} & : \text { 가압기 초기 압력 }(\mathrm{Pa}) \\ \mathrm{TO} & : \text { 가압기 초기 온도 }(\mathrm{K}) \\ \mathrm{RHOO} & : \text { 가압기 내 유체 초기 밀도 }\left(\mathrm{kg} / \mathrm{m}^{3}\right) \\ \mathrm{RHOA} & : \text { 배관내 비응축성 개스 초기 밀도 }\left(\mathrm{kg} / \mathrm{m}^{3}\right) \\ \mathrm{RHOW} & : \text { 배관내 물기둥 초기 밀도 }\left(\mathrm{kg} / \mathrm{m}^{3}\right) \\ \mathrm{PATM} & : \text { 대기 압력 }(\mathrm{Pa}) \\ \text { ZETA } & : \text { 배관 출구에 연결되는 증기분사기의 전체 압력 } \\ & \text { 강하 계수 }\end{array}$

$\mathrm{FR}, \mathrm{FS}, \mathrm{FQ}$ : 배관 마찰계수

VOT : 밸브 개방 시간 (sec.)

DTRT : 밸브 목 지름 $(\mathrm{m})$

$\mathrm{DO}$ : 배관 내경 $(\mathrm{m})$

HTC : 배관과 유체사이의 열전달계수 $\left(\mathrm{W} / \mathrm{m}^{2}-\mathrm{K}\right)$

TWALL : 배관벽의 온도 $\left({ }^{\circ} \mathrm{C}\right)$ 등 이다.

\section{3. 결과 및 토의}

안전감압시스템의 배관에서의 유동해석은 전산 코드를 개 발하여 현재 가동중인 가압경수로 영광 3,4 호기 배관계(Ju $\mathrm{K}, 1993$ )를 참고하여 Table 1을 작성하고 각각의 경우에 대 해 해석을 하였다.

가압기에서 안전감압시스템을 통해 $17.24 \mathrm{MPa}$ 의 포화증기 가 채워져 있으며, 방출밸브 대 방출배관 면적비를 $1: 10$, 방 출배관의 내경은 $36.67 \mathrm{~cm}$ 의 경우와 $20.32 \mathrm{~cm}$ 경우에 대해 분석하였고 밸브 개방 시간을 5 미리초 그리고 물에 잠김 깊 이는 $0.5 \mathrm{~m}$ 이며 밸브 후단과 물이 잠긴 부분까지의 배관 내 에는 공기가 차 있는 경우를 선정하였다.

마찰계수는 0.0215 로 전 배관에 일정하다고 가정하였으며 배관 전체 길이는 $26.1 \mathrm{~m}$ 경우와 $43.5 \mathrm{~m}$ 인 경우에 대해 분석 하였다. 그리고 저장 탱크의 수조압력을 $0.1 \mathrm{MPa}$ 로 유지하도 록 하였다.

Fig. 1 에서 Fig. 3 까지는 배관의 길이에서 $1 / 3$ 지점, $2 / 3$ 지 점 그리고 배관의 끝 지점에서의 압력을 시간에 따라 변화하 는 추이를 해석하여 얻은 결과다. 초기 안전감압시스템의 밸 브가 열리는 시점인 $17.24 \mathrm{MPa}$ 에서 밸브가 닫히는 시점인 $15.17 \mathrm{MPa}$ 까지 $0.69 \mathrm{MPa}$ 씩 변화를 주어가면서 각각의 경우 에 대한 분석을 수행하였다. Fig. 1 에서 0.08 초 지점에서 증 가되던 압력의 변화가 잠깐 감소되는 현상을 볼 수 있다. 이 는 압력파가 배관의 하단으로 전달되던 중에 물과 공기면에
Table 1. Case Map for Analysis of Pressure Variation at inside of Discharging Pipe

\begin{tabular}{|c|c|c|c|c|}
\hline Group & Case & $\begin{array}{c}\text { Initial } \\
\text { Pressure at } \\
\text { Pipe Inlet }\end{array}$ & $\begin{array}{c}\text { Factor2: } \\
\text { iameter } \\
\text { (DO) }\end{array}$ & $\begin{array}{c}\text { Factor3: } \\
\text { Pipe Length } \\
(\mathrm{DX} * \mathrm{NL})\end{array}$ \\
\hline \multirow{4}{*}{ Group A } & Case1 & $17.24 \mathrm{MPa}$ & $0.3667 \mathrm{~m}$ & $0.3 \mathrm{M} * 87=26.1 \mathrm{~m}$ \\
\hline & Case2 & $16.55 \mathrm{MPa}$ & $0.3667 \mathrm{~m}$ & $0.3 \mathrm{M} * 87=26.1 \mathrm{~m}$ \\
\hline & Case3 & $15.86 \mathrm{MPa}$ & $0.3667 \mathrm{~m}$ & $0.3 \mathrm{M} * 87=26.1 \mathrm{~m}$ \\
\hline & Case4 & $15.17 \mathrm{MPa}$ & $0.3667 \mathrm{~m}$ & $0.3 \mathrm{M} * 87=26.1 \mathrm{~m}$ \\
\hline \multirow{4}{*}{ Group B } & Case 5 & $17.24 \mathrm{MPa}$ & $0.2032 \mathrm{~m}$ & $0.3 \mathrm{M} * 87=26.1 \mathrm{~m}$ \\
\hline & Case6 & $16.55 \mathrm{MPa}$ & $0.2032 \mathrm{~m}$ & $0.3 \mathrm{M} * 87=26.1 \mathrm{~m}$ \\
\hline & Case 7 & $15.86 \mathrm{MPa}$ & $0.2032 \mathrm{~m}$ & $0.3 \mathrm{M} * 87=26.1 \mathrm{~m}$ \\
\hline & Case8 & $15.17 \mathrm{MPa}$ & $0.2032 \mathrm{~m}$ & $0.3 \mathrm{M} * 87=26.1 \mathrm{~m}$ \\
\hline \multirow{4}{*}{ Group C } & Case9 & $17.24 \mathrm{MPa}$ & $0.2032 \mathrm{~m}$ & $0.5 \mathrm{M} * 87=43.5 \mathrm{~m}$ \\
\hline & Case 10 & $16.55 \mathrm{MPa}$ & $0.2032 \mathrm{~m}$ & $0.5 \mathrm{M} * 87=43.5 \mathrm{~m}$ \\
\hline & Case 11 & $15.86 \mathrm{MPa}$ & $0.2032 \mathrm{~m}$ & $0.5 \mathrm{M} * 87=43.5 \mathrm{~m}$ \\
\hline & Case 12 & $15.17 \mathrm{MPa}$ & $0.2032 \mathrm{~m}$ & $0.5 \mathrm{M} * 87=43.5 \mathrm{~m}$ \\
\hline \multirow{4}{*}{ Group D } & Case 13 & $17.24 \mathrm{MPa}$ & $0.3667 \mathrm{~m}$ & $0.5 \mathrm{M} * 87=43.5 \mathrm{~m}$ \\
\hline & Case 14 & $16.55 \mathrm{MPa}$ & $0.3667 \mathrm{~m}$ & $0.5 \mathrm{M} * 87=43.5 \mathrm{~m}$ \\
\hline & Case 15 & $15.86 \mathrm{MPa}$ & $0.3667 \mathrm{~m}$ & $0.5 \mathrm{M} * 87=43.5 \mathrm{~m}$ \\
\hline & Case 16 & $15.17 \mathrm{MPa}$ & $0.3667 \mathrm{~m}$ & $0.5 \mathrm{M} * 87=43.5 \mathrm{~m}$ \\
\hline
\end{tabular}

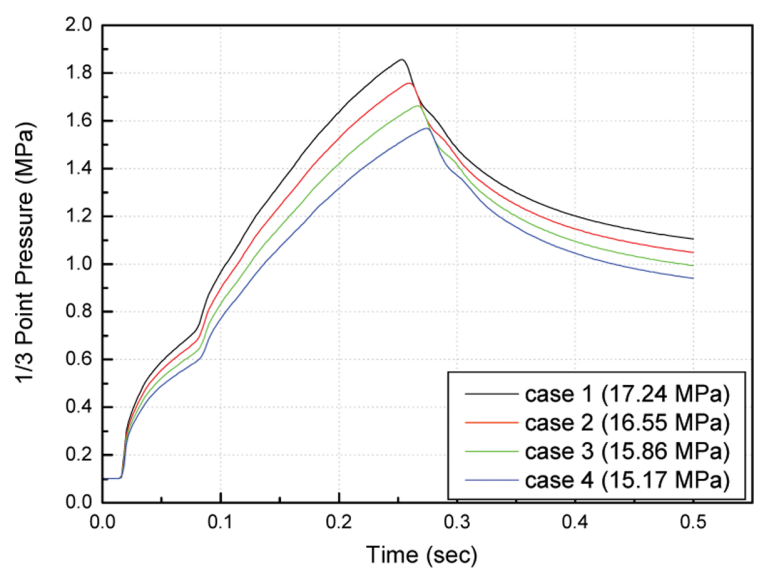

Fig. 1. Pressure Variation at $1 / 3$ of Pipe Length $(f=0.0215$, $\mathrm{L}=26.1 \mathrm{~m}, \mathrm{D}=0.3667 \mathrm{~m}$, Initial Pressure 17.24 $\mathrm{MPa} \sim$ $15.17 \mathrm{MPa})$

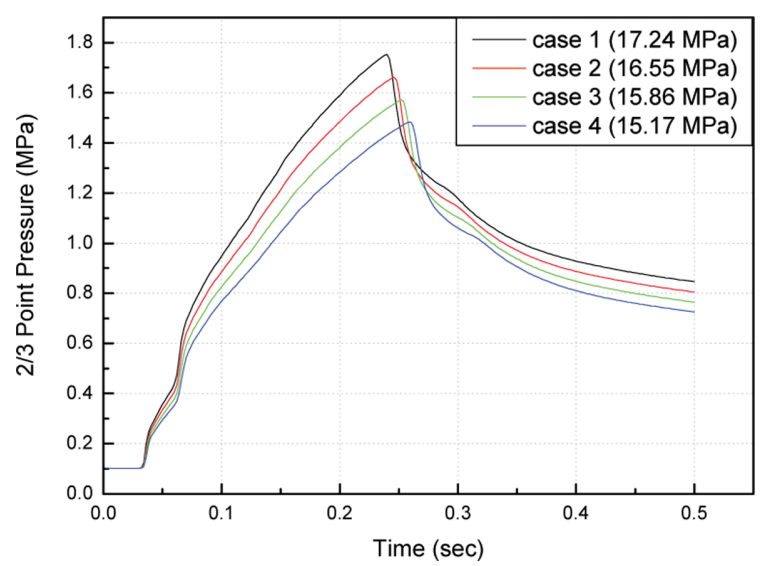

Fig. 2. Pressure Variation at $2 / 3$ of Pipe Length $(f=0.0215$, $\mathrm{L}=26.1 \mathrm{~m}, \mathrm{D}=0.3667 \mathrm{~m}$, Initial Pressure $17.24 \mathrm{MPa} \sim$ 15.17 MPa) 


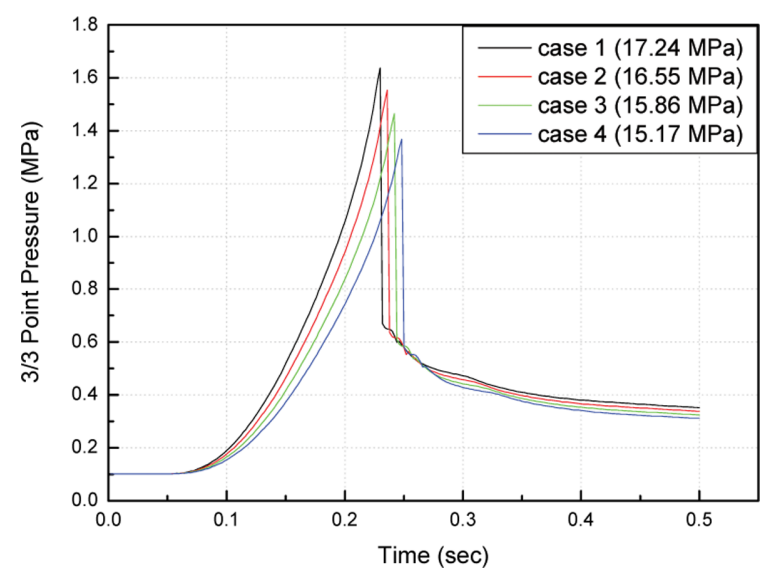

Fig. 3. Pressure Variation at end of Pipe $(f=0.0215, L=26.1 \mathrm{~m}$, $\mathrm{D}=0.3667 \mathrm{~m}$, Initial Pressure 17.24 $\mathrm{MPa} \sim 15.17 \mathrm{MPa}$ )

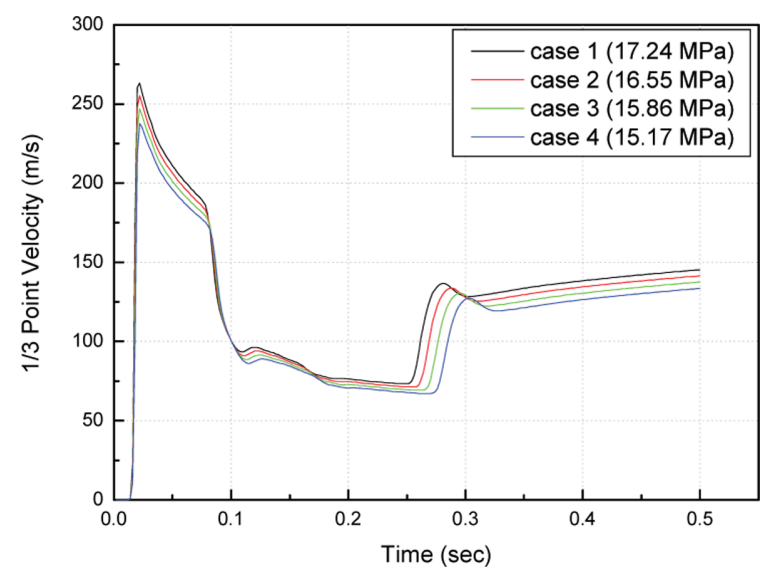

Fig. 4. Velocity Variation at $1 / 3$ of Pipe Length $(f=0.0215$, $\mathrm{L}=26.1 \mathrm{~m}, \mathrm{D}=0.3667 \mathrm{~m}$, Initial Pressure $17.24 \mathrm{MPa}$ 15.17 MPa)

서의 압력 반송이 압력 증가 변화에 영향을 주고 있는 현상 을 설명해 주고 있다. 이같이 압력 반송의 영향은 Fig. 2에 서 보여 주는 것처럼 $2 / 3$ 지점에서는 $1 / 3$ 지점에서 보다 다소 일찍 영향을 보이고 있음을 알 수 있다.

Fig. 3의 배관 하단에서의 압력 변화는 시간이 대략 0.23 초가 경과한 후 급격한 압력 하강의 현상을 보여 주고 있다. 이 시점은 배관 하단에 차 있었던 물이 완전히 배관을 빠져 나간 시점에서 압력의 변화를 보여 주고 있는 것이다. 이 시 점이 Water Clearing되는 시점임을 알 수 있다.

Fig. 4에서 Fig. 6까지는 같은 조건에서 유량 속도의 변화 를 보여 주고 있다. Fig. 4에서 보여 주듯이 초기에 유량의 속도가 갑작스럽게 증가하다가 0.025 초 시점부터 서서히 속 도가 감소되는 현상을 보인다. 이어 Fig. 1에서 Fig. 3까지는 앞의 압력 변화에서와 같이 반압으로 인한 영향으로 0.08 초 에서 속도가 큰 폭으로 감소함을 알 수 있다. 0.226초 이후 에는 유량의 속도가 다시 큰 폭으로 증가하고 있음을 보여 주고 0.32 초 이후부터는 유량의 속도가 안정적으로 유지되고 있음을 나타낸다. 이는 배관 하단에서 반압의 영향을 주고 있었던 물이 빠져나가면서 일정한 압력과 속도가 유지되고 있음을 나타내고 있다.

Fig. 7에서 Fig. 11까지의 데이터는 초기 압력이 $17.24 \mathrm{MPa}$

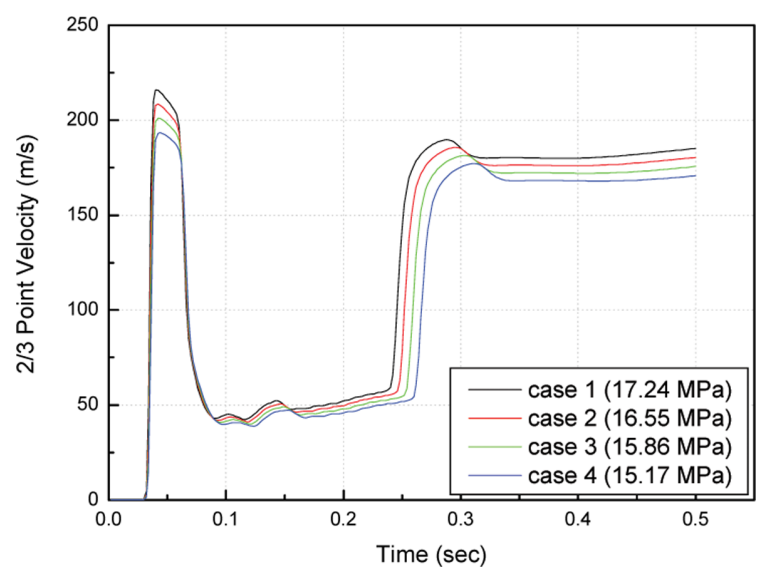

Fig. 5. Velocity Variation at $2 / 3$ of Pipe Length $(f=0.0215$, $\mathrm{L}=26.1 \mathrm{~m}, \mathrm{D}=0.3667 \mathrm{~m}$, Initial Pressure $17.24 \mathrm{MPa} \sim$ 15.17 MPa)

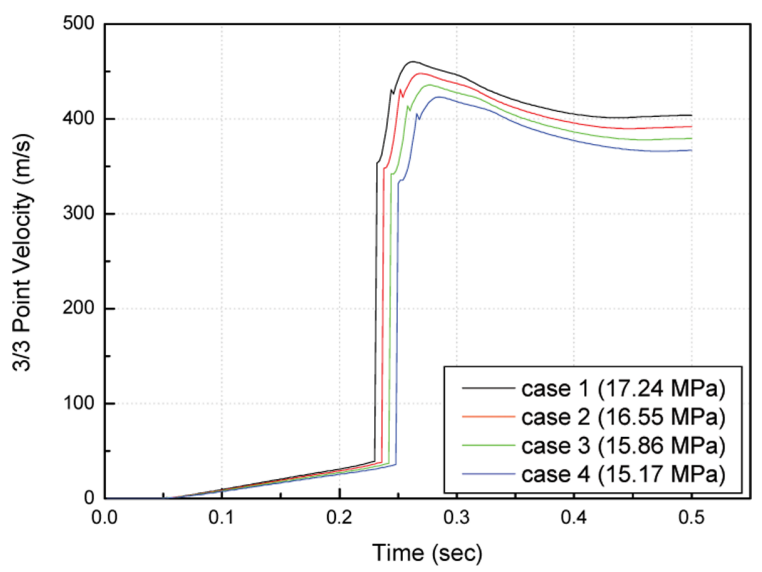

Fig. 6. Velocity Variation at end of Pipe Length $(f=0.0215$, $\mathrm{L}=26.1 \mathrm{~m}, \mathrm{D}=0.3667 \mathrm{~m}$, Initial Pressure $17.24 \mathrm{MPa}$ $15.17 \mathrm{MPa}$ )

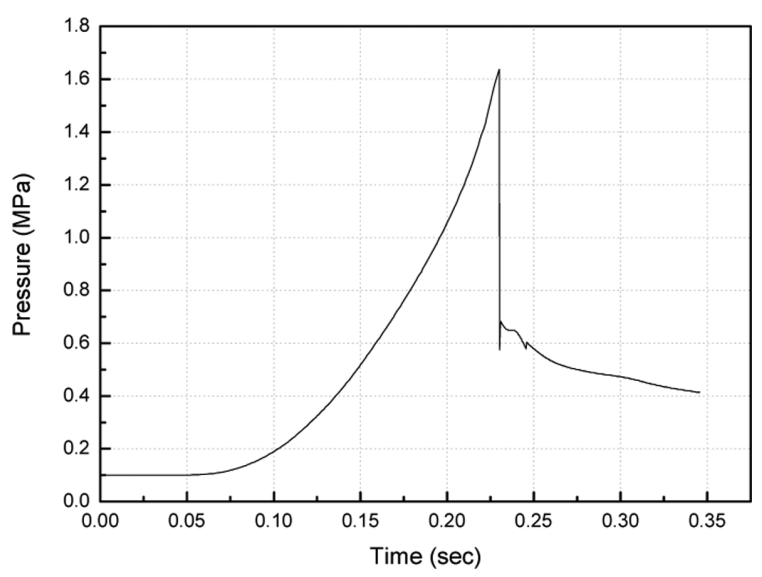

Fig. 7. Pressure Variation at end of Pipe vs Time (Pressure $=17.24 \mathrm{MPa}, \mathrm{f}=0.0215, \mathrm{~L}=26.1 \mathrm{~m}$ )

경우에 배관의 하단 끝에서 압력, 유량 속도, 음속도, 밀도, 온도 및 증기 유량의 변화를 보여 주고 있다. Fig. 3에서와 마찬가지로 Fig. 7의 대략 0.23초 시점에서 배관내의 차 있 었던 물이 수조로 빠져나가고, 공기가 이를 통과하고 있는 현상을 보임을 알 수 있다.

Fig. 8에서는 유량의 속도가 비슷한 시간에서 속도가 큰 


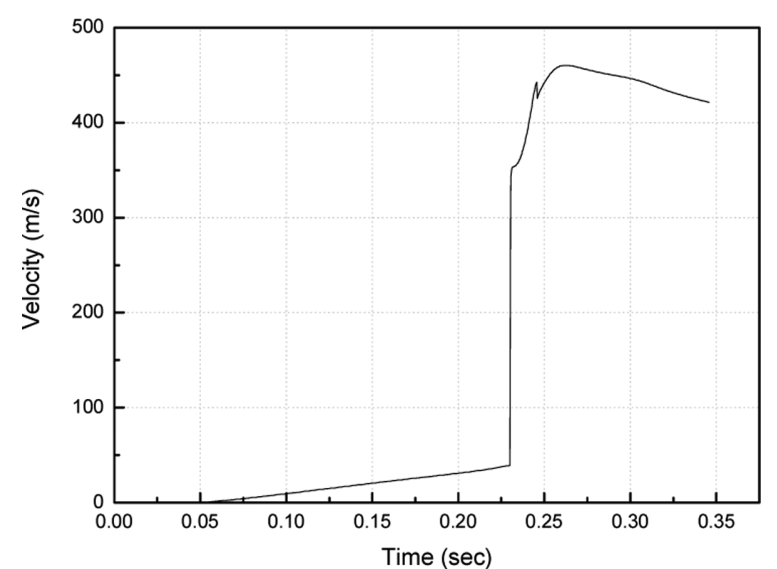

Fig. 8. Velocity Variation at end of Pipe vs Time (Pressure $=17.24 \mathrm{MPa}, \mathrm{f}=0.0215, \mathrm{~L}=26.1 \mathrm{~m}$ )

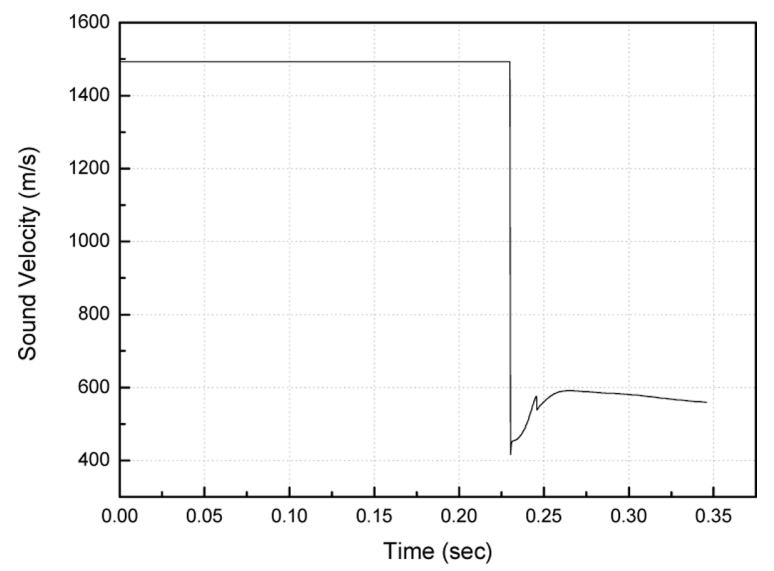

Fig. 9. Sound Velocity Variation at end of Pipe vs Time (Pressure=17.24 MPa, f=0.0215, L=26.1 m)

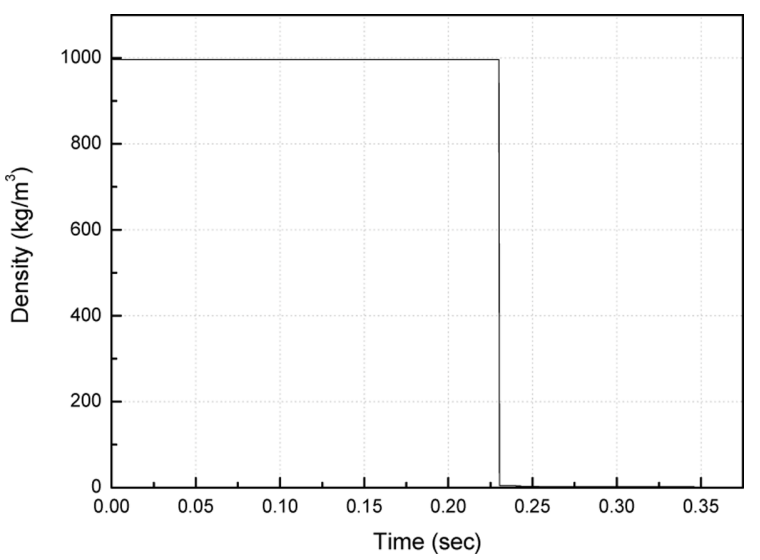

Fig. 10. Density Variation at end of Pipe vs Time (Pressure $=17.24 \mathrm{MPa}, \mathrm{f}=0.0215, \mathrm{~L}=26.1 \mathrm{~m}$ )

폭으로 증가하고 있음을 알 수 있으며 Fig. 9, Fig. 10 그리 고 Fig. 11에서의 음속도, 밀도 그리고 온도의 변화도 같은 시점에서 크게 변화를 했음을 알 수 있다. Fig. 12에서 보여 주는 유량의 변화도 지속적으로 증가하다가 같은 시점에서 물이 완전히 빠져나가면서 더 이상의 유량은 존재하지 않고 있음을 보여주고 있다.

Fig. 13과 Fig. 14는 초기 배관 입구 압력이 $17.24 \mathrm{MPa}$

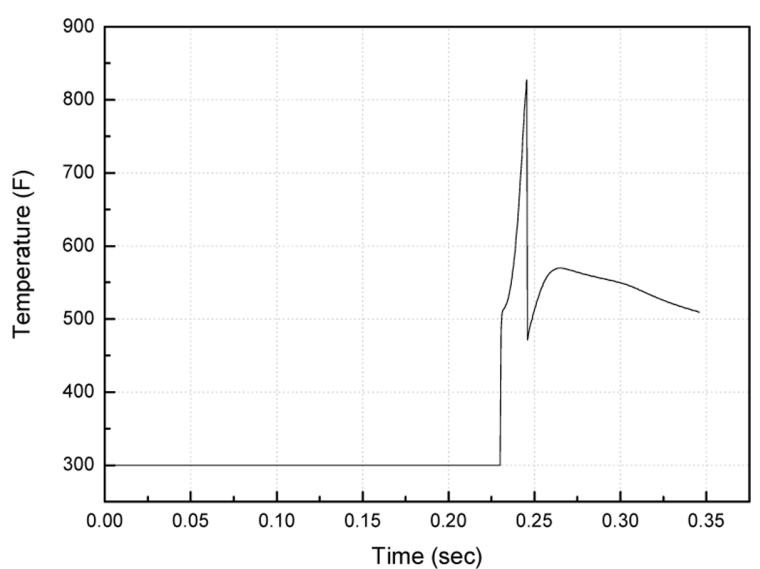

Fig. 11. Temperature Variation at end of Pipe vs Time (Pressure=17.24 MPa, $\mathrm{f}=0.0215, \mathrm{~L}=26.1 \mathrm{~m}$ )

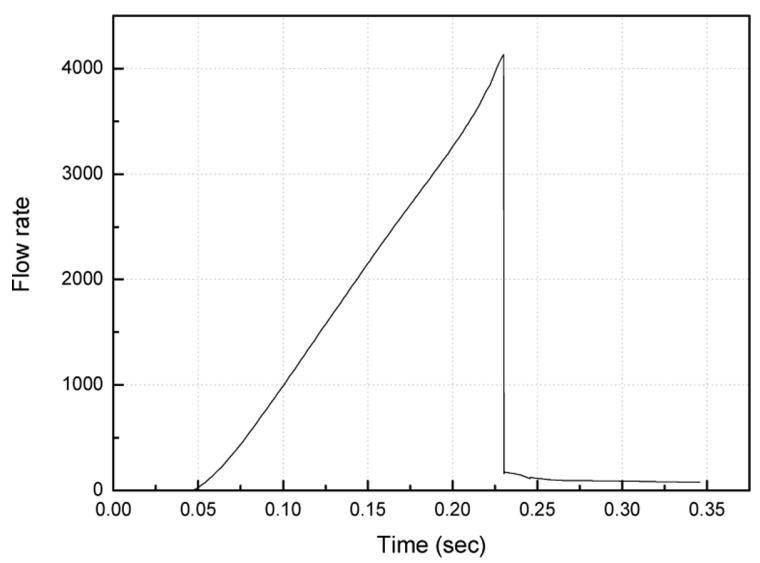

Fig. 12. Flow Rate Variation at end of Pipe vs Time (Pressure=17.24 MPa, $\mathrm{f}=0.0215, \mathrm{~L}=26.1 \mathrm{~m}$ )

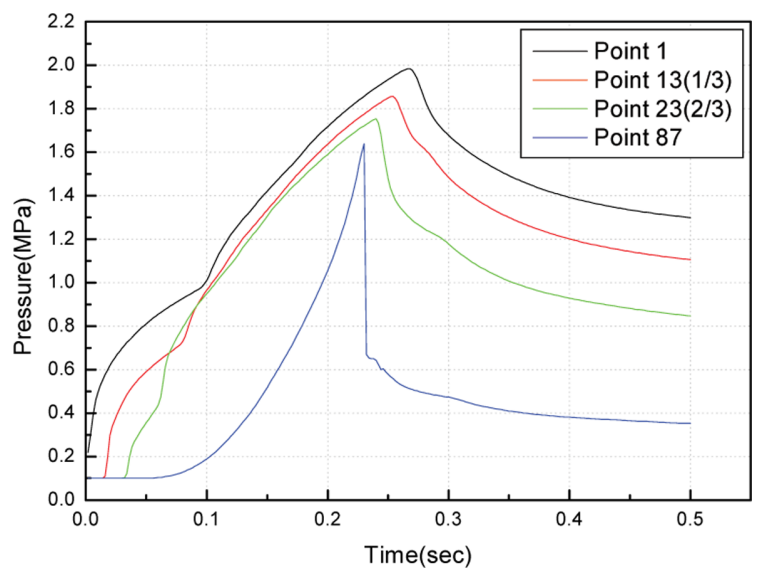

Fig. 13. Pressure Variation at each Point of Pipe (Initial Pressure $=17.24 \mathrm{MPa}, \mathrm{f}=0.0215, \mathrm{~L}=26.1 \mathrm{~m}$ )

조건에서 배관의 입구, $1 / 3$ 지점, $2 / 3$ 지점 그리고 끝부분에서 압력과 속도의 변화를 보여 주고 있다. 각 구간별로 압력파 가 전달되는 시간이 있음을 보여주고 있으며 배관의 유동 조 건에 따라 압력 및 속도의 변화를 나타내고 있다.

Fig. 15에서 Fig. 18 까지의 데이터는 초기 배관의 압력이 17.24 MPa조건에서 전체 배관 길이에서 시간별 변화되는 압 력, 속도, 음속도, 밀도의 변화를 보여 주는 자료이다. Fig. 


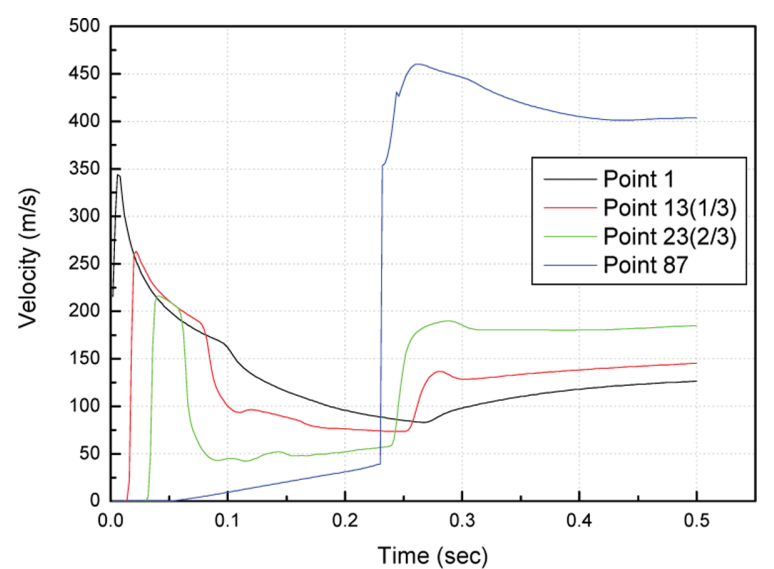

Fig. 14. Velocity Variation at each Point of Pipe (Initial Pressure $=17.24 \mathrm{MPa}, \mathrm{f}=0.0215, \mathrm{~L}=26.1 \mathrm{~m}$ )

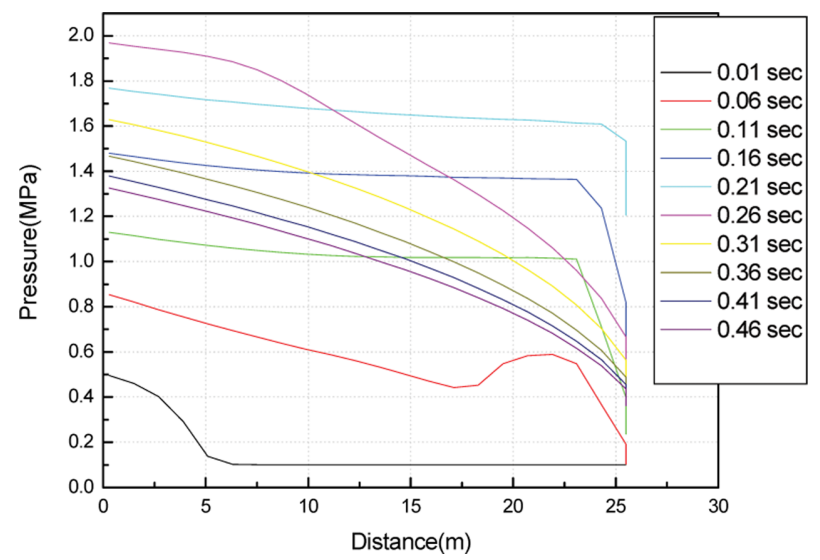

Fig. 15. Pressure Variation at each Point of Pipe vs Time (Initial Pressure=17.24 MPa, $f=0.0215, L=26.1 \mathrm{~m}$ )

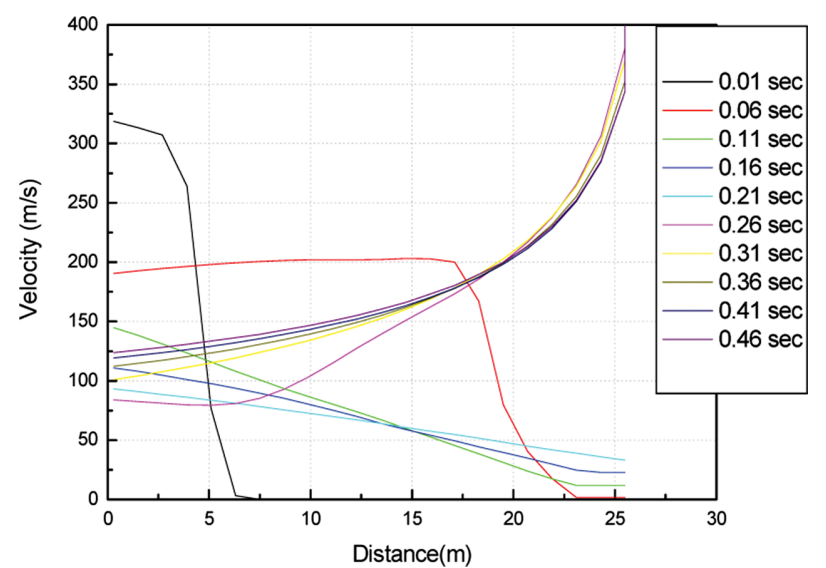

Fig. 16. Velocity Variation at each Point of Pipe vs Time (Initial Pressure=17.24 MPa, $f=0.0215, L=26.1 \mathrm{~m}$ )

15 에서 초기 0.01 초의 경우에는 압력이 $5 \mathrm{~mm}$ 까지만 전달되 었음을 알 수 있고, 0.06 초 시점에는 이미 압력파가 배관 하 단부까지 전달되고 배관에 차있던 물의 반압으로 압력이 역 으로 증가되고 있음을 알 수 있다. 그리고 0.21 초가 지난 후 에 0.26 초에서는 물이 배관을 빠져 나감으로서 급격히 압력 이 줄어 들고 있음을 보여주고 있다.

Fig. 19 는 관의 길이가 $26.1 \mathrm{~m}$ 이고, 관의 직경이 각

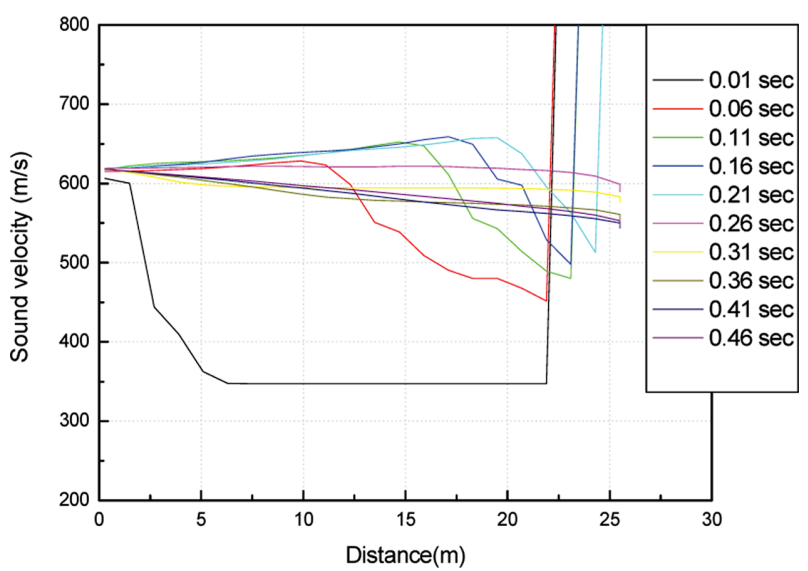

Fig. 17. Sound Velocity Variation at each Point of Pipe vs Time (Initial Pressure=17.24 MPa, $\mathrm{f}=0.0215, \mathrm{~L}=26.1 \mathrm{~m}$ )

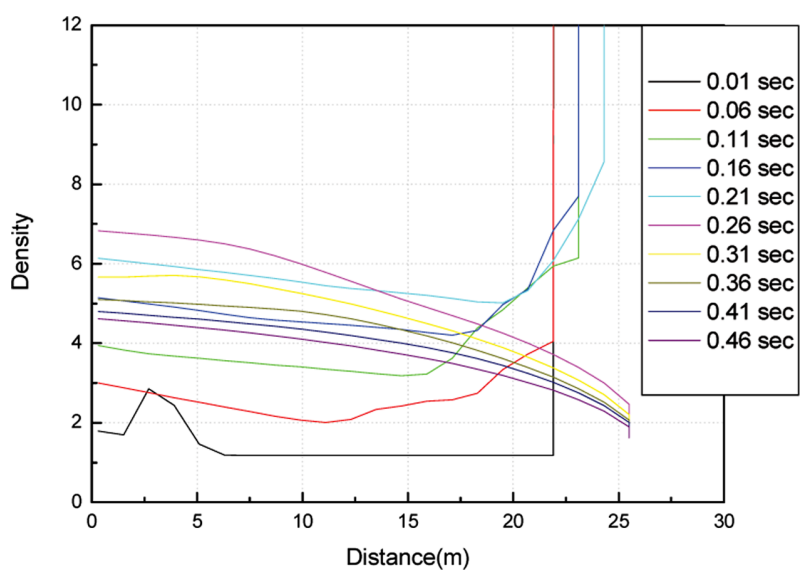

Fig. 18. Density Variation at each Point of Pipe vs Time (Initial Pressure $=17.24 \mathrm{MPa}, \mathrm{f}=0.0215, \mathrm{~L}=26.1 \mathrm{~m}$ )

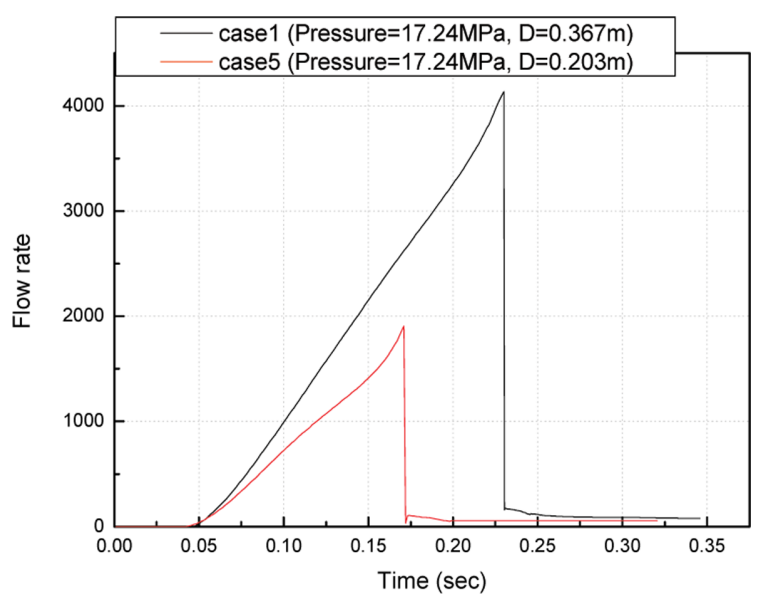

Fig. 19. Flow Rate Variation at Case 1 vs Case $5(f=0.0215$, $\mathrm{L}=26.1 \mathrm{~m}$ )

$0.2032 \mathrm{~m}$ 와 $0.3667 \mathrm{~m}$ 일 경우에 유량에 대한 데이터로 배관 의 직경이 증가함에 따라 유량의 변화폭은 크게 나타났으며 물이 배관을 빠져나가는 water clearing 시점은 배관의 직경 이 작은 상황에 비하여 늦음을 나타내고 있다. 이와 같은 현 상은 배관의 길이가 $26.1 \mathrm{~m}$ 에서 $43.5 \mathrm{~m}$ 로 변경된 Fig. 20 의 경우에서도 동일한 결과를 얻을 수 있었다. 배관의 길이가 


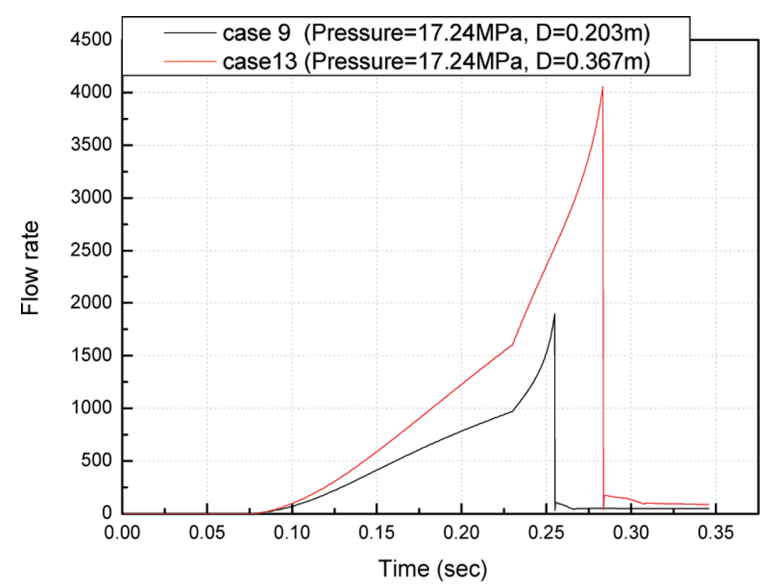

Fig. 20. Flow Rate Variation at Case 9 vs Case $13(\mathrm{f}=0.0215$, $\mathrm{L}=43.5 \mathrm{~m}$ )

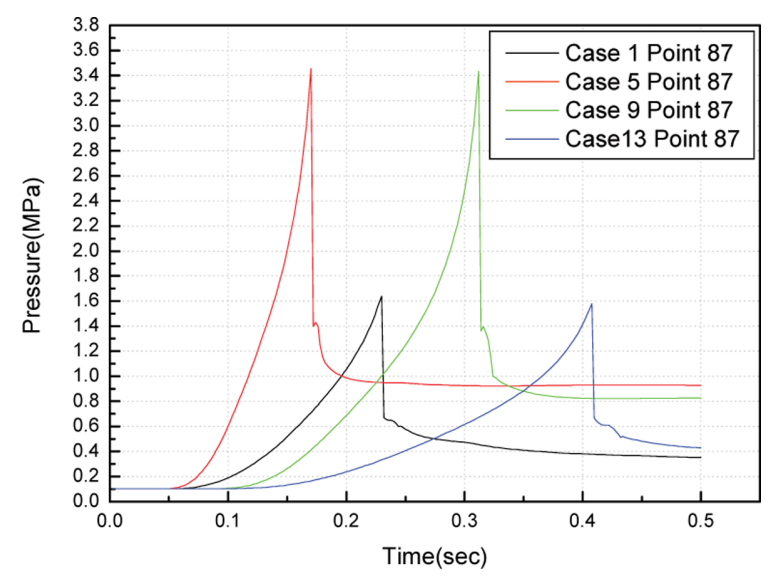

Fig. 21. Pressure Variation of Inlet of Pipe at Each Case $(\mathrm{f}=0.0215)$

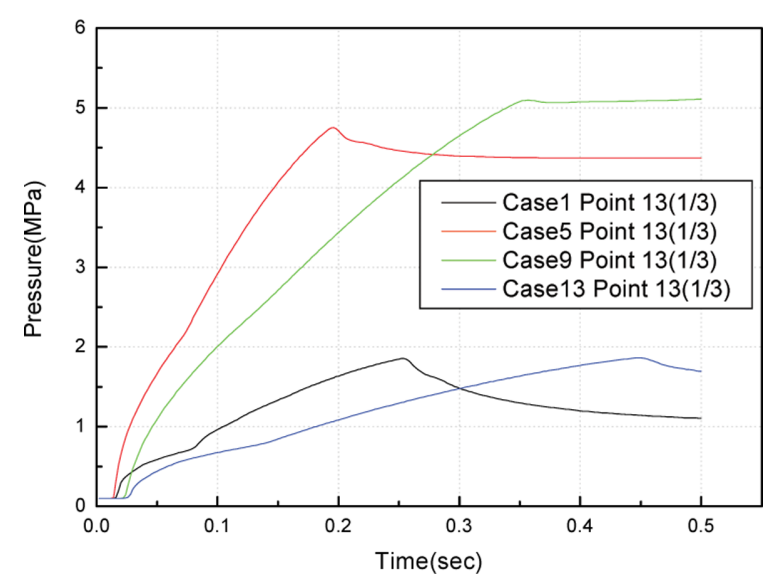

Fig. 22. Pressure Variation of $1 / 3$ Pipe Length at Each Case $(f=0.0215)$

길어진 경우에는 중간에 반압으로 영향이 한차례 더 발생하 였음을 알 수 있는 유량의 구배가 있었다.

Fig. 21 에서 Fig. 24 까지의 데이터는 배관의 각 지점에서 초기 압력의 조건이 $17.24 \mathrm{MPa}$ 경우에 배관의 직경과 길이 가 다를 경우에 대해 해석한 자료를 보여주고 있다. Fig. 21 에서 배관의 길이가 $26.1 \mathrm{~m}$ 인 Case 1과 Case 5 의 경우는 관의 작경이 작은 Case 5 에서 초기 압력의 증폭이 가장 크

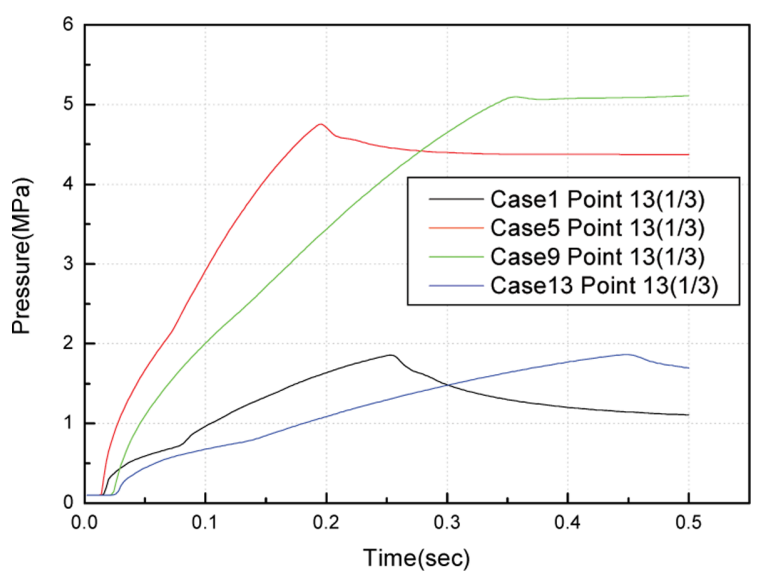

Fig. 23. Pressure Variation of $2 / 3$ Pipe Length at Each Case $(\mathrm{f}=0.0215)$

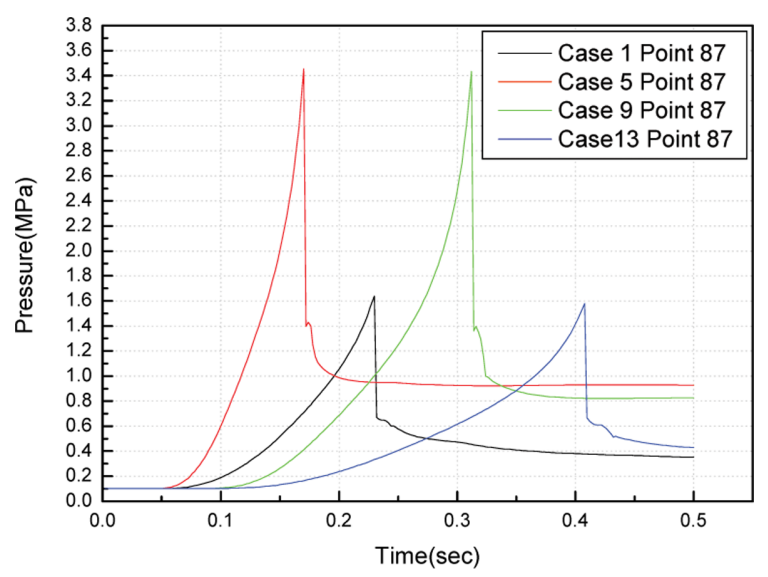

Fig. 24. Pressure Variation of end of Pipe at Each Case $(\mathrm{f}=0.0215)$

게 나타나고 있음을 알 수 있었고 상대적으로 배관의 길이가 길고 배관의 직경이 큰 경우에는 압력의 변화가 다른 3 개의 경우에 비해 상당히 안정적으로 변화를 하고 있음을 알 수 있었다. 또한 Fig. 24의 배관 끝부분에서 나타나는 현상처럼 관의 직경이 작고 관의 길이가 가장 작은 Case 5 의 경우가 가장 빠른 속도로 물이 빠져 나갔음을 알 수 있었고, 관의 길이가 상대적으로 길고 관의 직경도 큰 Case 13 에서 물이 가장 느리게 빠져 나가는 현상을 볼 수 있었다.

\section{5. 결 론}

1) 밸브가 열린 후 약 배관의 2/3지점까지는 배관의 압력 이 초기 배관 압력인 $17.24 \mathrm{MPa}$ 최대 $15 \%$ 이상인 $19.9 \mathrm{MPa}$ 까지 높았음을 알 수 있었다. 이는 배관 하단 부로부터의 반압이 있은 후, 이로 인해 압력이 급격히 상승하였음을 알 수 있었다. 이는 배관 설계시 배관 하 단부로부터의 반압으로 인해 추가적인 압력 상승이 배관 의 상부에 미칠 수 있음을 보여 주는 현상으로, 배관의 설계시 실제 배출 압력보다 설계치를 높게 설계해야 함 을 알 수 있었다. 이와 더불어, 배관 지지대의 설계를 위한 기초 입력 자료로서 실제 운전 압력보다 충분한 
Margin을 갖은 설계를 해야 함을 알 수 있었다.

2) 배관길이에 따른 압력의 변화를 고찰한 결과를 보면, 초 기의 압력파가 대략 0.075 초 이후부터 배관 하단부분의 물로 인한 반압의 영향이 있었고, 대략 $0.1 \mathrm{MPa}$ 정도 감압되었음을 알 수 있었다. 이러한 현상은 배관의 상단 부가 배관의 하단부보다 물에 의한 반압의 영향이 크게 나타남을 알 수 있었다. 이는 추후 배관 설계 시에 물 때문에 발생하는 반압의 크기 정도를 정확히 파악할 필 요성이 있고 이에 따른 해당 부분에 지지대의 설계에 참고가 되겠다. 이와 같은 정보는 유량의 속도결과로부 터 다시 확인할 수 있었다.

3) 배관길이에 따른 압력과 유량의 속도 변화에서 보여주는 것처럼 압력파가 배관 입구에서 하단으로 전달된 후, 대 략 0.23 초 이후 시점에서 배관속의 물이 배관으로부터 빠져 나갔음을 알 수 있고, 이는 배관의 길이와 직경의 차이에 따라 각각 시간과 압력의 변화 현상이 다름을 알 수 있었다. 따라서 배관의 직경 및 길이에 따른 배 관 설계 및 배관 지지도의 설계가 달리 수행되어야 함 을 알 수 있었다.

4) 배관의 직경과 길이가 다를 경우의 해석 결과를 비교해 본 결과, 배관의 단면적이 3.25 배 정도 증가된 경우(직경 이 $0.3667 \mathrm{~m}$ 인 경우) 압력의 최대값은 직경이 $0.2062 \mathrm{~m}$ 인 경우에 비해 2.8 배정도 낮아졌음을 알 수 있었다.
실제 APR에서는 배관의 크기를 $0.2032 \mathrm{~m}$ 로서 보다 상 세 배관 설계시 배관 직경에 따른 배관내에서의 압력 변화에 대한 자료를 바탕으로 현재 설계값에 대한 타당 성 검토가 필요하겠다.

\section{References}

H.H. Safwat, Analysis of the Safety Relief Valve Discharge Transiensts of a Boiling Water Reactor, 2nd International Conference on Pressure Surges, 1976, pp. E1/1-E1/17.

From B.T. Lubin to R.S. Turk, System 80+ : Evaluation of SRS and IRWST Designs; Summary of Design Review Meeting, FSP92-011, Jan. 30,1992.

S. Nakamura, Computational Methods in Engineering and Science, John Wiley \& Sons, 1977.

D.A. Anderson et al., Computational Fluid Mechanics and Heat Transfer, McGraw Hill, 1984.

F.G. Hammitt, Cavitation and Multiphase Flow Phenomena, McGraw-Hill, 1980.

Crane, Flow of Fluids through Valves, Fittings and Pipe, CRANE Co., 1982

Ju K. S-common-93-060: Young Kwang 5\&6 SDS desing support reference, 1993.

\footnotetext{
(2) Received April 1, 2013

() Revised April 19, 2013

(a) Accepted June 14, 2013
} 